\title{
Saline Soils: A Potentially Significant Geoheritage of the Vojvodina Region, Northern Serbia
}

\author{
Tijana Zeremski ${ }^{1, *(\mathbb{D}, \text { Nemanja Tomić }}{ }^{2}$, Stanko Milić ${ }^{1}{ }^{\circledR}$, Jovica Vasin ${ }^{1}$, Randall J. Schaetzl ${ }^{3}$, Dubravka Milić ${ }^{4}$, \\ Milivoj B. Gavrilov ${ }^{2}$, Milorad Živanov ${ }^{1}$, Jordana Ninkov ${ }^{1}$ (i) and Slobodan B. Marković ${ }^{2}$
}

1 Institute of Field and Vegetable Crops, Maksima Gorkog 30, 21000 Novi Sad, Serbia; stanko.milic@ifvens.ns.ac.rs (S.M.); jovica.vasin@ifvens.ns.ac.rs (J.V.); milorad.zivanov@ifvens.ns.ac.rs (M.Ž.); jordana.ninkov@ifvens.ns.ac.rs (J.N.)

2 Department of Geography, Tourism and Hotel Management, Faculty of Sciences, University of Novi Sad, Trg Dositeja Obradovića 3, 21000 Novi Sad, Serbia; airtomic@gmail.com (N.T.); gavrilov.milivoj@gmail.com (M.B.G.); slobodan.markovic@dgt.uns.ac.rs (S.B.M.)

3 Department of Geography, Environment, and Spatial Sciences, Michigan State University, 673 Auditorium Rd., East Lansing, MI 48824, USA; soils@msu.edu

4 Department of Biology and Ecology, Faculty of Sciences, University of Novi Sad, Trg Dositeja Obradovića 3, 21000 Novi Sad, Serbia; dubravka.milic@dbe.uns.ac.rs

* Correspondence: tijana.zeremski@ifvcns.ns.ac.rs

Citation: Zeremski, T.; Tomić, N.; Milić, S.; Vasin, J.; Schaetzl, R.J.; Milić, D.; Gavrilov, M.B.; Živanov, M.;

Ninkov, J.; Marković, S.B. Saline Soils: A Potentially Significant Geoheritage of the Vojvodina Region, Northern Serbia. Sustainability 2021, 13, 7891. https://doi.org/10.3390/su13147891

Academic Editor: Chunjiang An

Received: 28 May 2021

Accepted: 12 July 2021

Published: 14 July 2021

Publisher's Note: MDPI stays neutral with regard to jurisdictional claims in published maps and institutional affiliations.

Copyright: (c) 2021 by the authors. Licensee MDPI, Basel, Switzerland. This article is an open access article distributed under the terms and conditions of the Creative Commons Attribution (CC BY) license (https:// creativecommons.org/licenses/by/ $4.0 /)$.

\begin{abstract}
Halomorphic (or saline) soils, are characterized by high concentrations of soluble salts or sodium, or both. Saline soils have unfavorable agricultural properties but provide the natural habitats for a variety of highly specialized plants, animals, and other organisms. It is these special interactions that create the typical landscape of saline soils, known as "slatina". The aim of this study is to assess and evaluate the geotouristic potential of six of the most attractive slatina sites in the Vojvodina region, Northern Serbia: Jegrička, Slano Kopovo, Rusanda, Okanj, Pečena slatina, and Pašnjaci Velike Droplje. Overall, all analyzed sites have significant tourism potential, based on both natural and tourist values. In addition to the tourism potentials, analyzed sites have high value as a natural endemic ecosystem inhabited with highly specialized plants and birds.
\end{abstract}

Keywords: saline soil; slatina; Vojvodina region; geotourism; geoheritage

\section{Introduction}

Although soil can be defined differently based on its specific purpose in nature or human society, in all definitions one fact remains the same-soil is one of Earth's most important natural resources. Throughout history, soils have provided the foundation for most of the critical aspects of civilization [1,2]. Soils are the basis of food production systems, and the cultivation of vegetation for food, fiber, and fuel. In addition, soils play a key role in regulating Earth's climate, and help to provide for clean water and help to preserve our cultural heritage and landscapes. Soils are the host to $\approx 25 \%$ of our planet's biodiversity, including most animals, plants, and many microorganisms [3].

Soils are complex and diverse natural systems, with broad spectra of chemical, physical and biological properties. Recently, pedodiversity has become a topic of some importance, while topics related to the role of soils in natural and cultural heritage are less commonly discussed $[4,5]$.

Halomorphic (or saline) soils, are characterized by high concentrations of soluble salts or sodium, or both. These soils have minor importance for agriculture due to their saline characteristics [6-8]. Nonetheless, saline soils are widespread worldwide, occupying $\approx 950$ Mha $(\approx 7 \%)$ of Earth's total land, or nearly $33 \%$ of potential agricultural land area $[9,10]$.

Despite the generally unfavorable agricultural properties of saline soils, they often serve as a unique ecosystem, as they are often inhabited by extremophilic organisms with 
very specific adaptation strategies. The true value of salty soils lies also in the treasurable endemic natural ecosystems which they host. Saline soils provide the natural habitats for a variety of highly specialized plants, animals, and other organisms. It is these special interactions that create the typical landscape of saline soils, known as "slatina". Here, these landscapes are primarily located in the northern part of Serbia, i.e., in the Vojvodina region. This region is well known for its intensive agricultural production with $\approx 75 \%$ of its territory under crops and other agricultural usage [11]. In the Vojvodina region, saline soils comprise only a small group of soils not influenced by agricultural production. Thus, slatina zones preserve many relict components of the natural landscape and provide high potentials for the development of geotourism and other sustainable activities important to rural development.

The aim of this study is to determine the current state and geotourism potential of six of the most attractive slatina sites in the Vojvodina region. To achieve this, the first step was to create a methodology encompassing all the important elements necessary for such an assessment. Therefore, the principal goal of this paper was to construct a unique soil assessment model for the assessment of soil sites as tourism destinations. By applying this methodology on the six selected slatina sites, the main intention was to detect and show which sites have the largest potential for future geotourism development and to provide information about key elements of the current tourism offer that still require improvement.

\section{The Main Characteristics of Saline Soils in Vojvodina}

Saline soils typically develop in arid and semi-arid climate zones, as well as in coastal regions in all climate zones. However, the occurrence of saline soils in Vojvodina (Figure 1) is not completely related to the climatic conditions. Instead, the formation of saline soils in the Vojvodina region is primarily dependent on local geomorphogical and hydrological characteristics.

In this region, salts derive from the Alps and Carpathian Mountains, which surround the Pannonian Plain on the eastern, northeastern and northern sides. Salts are primary produced after weathering of the different eruptive and metamorphic rocks, and transported by rivers to the alluvial lowlands of the Vojvodina region. In Vojvodina, saline soils on alluvial plains of the Danube, Tisa, Sava, Begej, and Tamiš Rivers, as well as on river terraces, are especially endangered. Saline soils here can be considered hydrogenic in origin, having formed due to the ascending and descending movement of salts in saline groundwater [12] During the seasonal fluctuations of groundwater or during the upwelling of salinized deep thermo-mineralized waters, significant amounts of salts accumulate in the upper layers of soils, particularly in depressional areas [13]. For that reason, saline soils in Vojvodina are mostly found in alluvial river plains or in depressions of relict fluvial land forms, characterized by shallow water tables. Here, saline soils are widespread within wetlands, where they are intermixed with salt lakes, salt marshes, and salt flats.

The investigations of saline soils in the Vojvodina region began in the second half of the 19th century, when the region was part of Austro-Hungarian Empire [14]. Successive studies were completed by Sigmond [15-17] and Treitz [18-20].

The systematic pedological mapping of Vojvodina accelerated the exploration of the characteristics of the region's saline soils. This endeavor was then boosted by the growth of intensive agricultural production [21,22]. In recent decades, this kind of research on soils has waned, even as the investigation of saline soils from different aspects, such as biological and environmental, started to grow.

Based on previous intensive research on saline soils, it has been estimated that halomorphic/saline soils cover $\approx 10.6 \%$ of total territory of the Vojvodina Province [23]. However, because the process of salinization is more rapid than most of other pedogenic processes, saline soils are susceptible to changes in their soil taxonomy status, even over short timespans. In addition to the natural processes responsible for saline soils genesis, secondary salinization can occur due to human activities, mainly by irrigation with slightly saline water, or generally by irrigation coupled with poor drainage conditions. Because of the 
widespread occurrence of irrigation worldwide, coupled with global climate change toward (in many areas) increase aridity, salinization processes are increasing the extent of halomorphic soils every year [24].

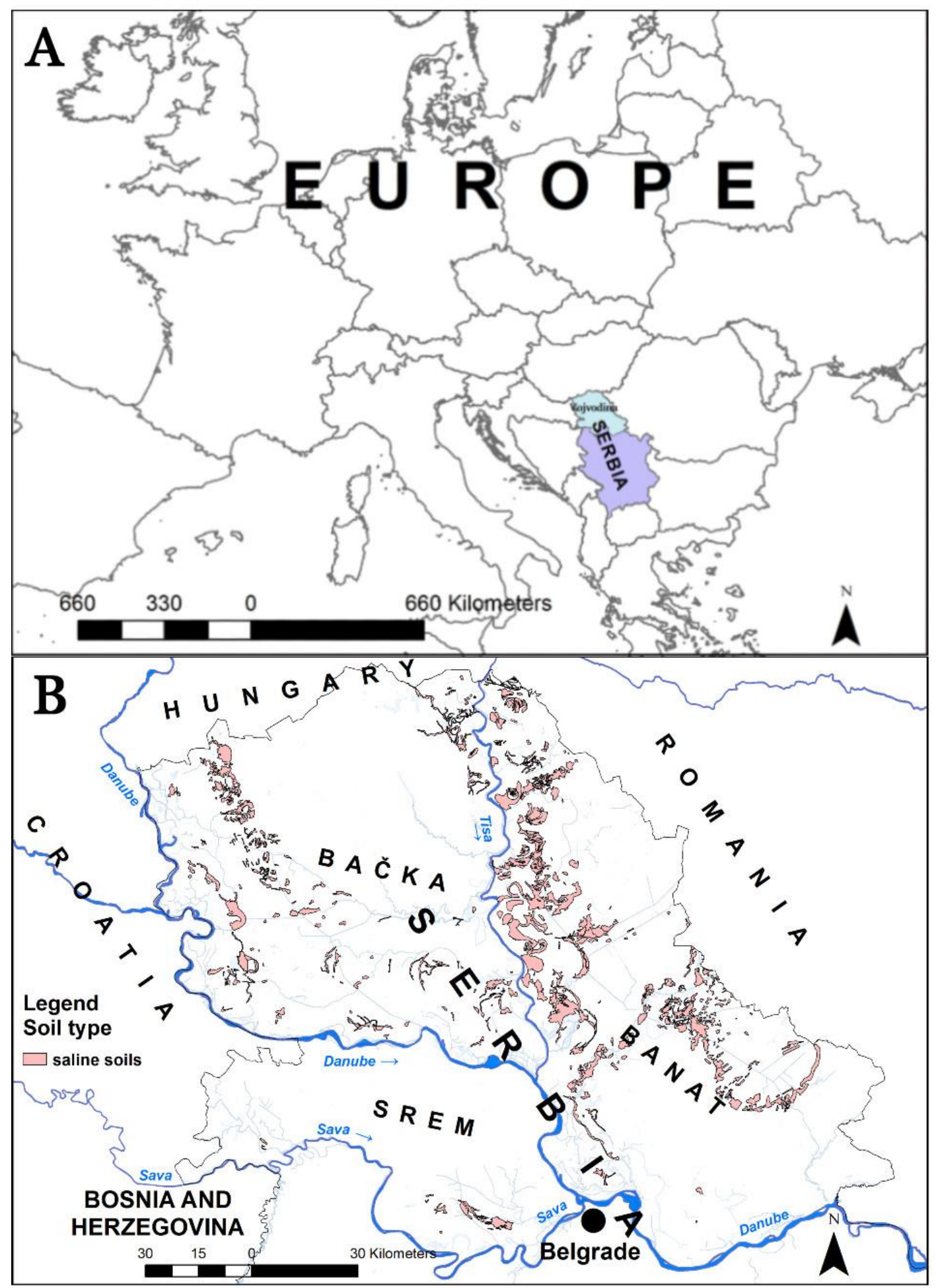

Figure 1. The geographical position of (A) Serbia and the Vojvodina region, and the distribution of saline soils across the Vojvodina region (B).

According to Serbian soil classification [25], the morphology, i.e., thickness and distribution of pedogenic horizons, of halomorphic soils are not typically the best diagnostic criteria for their classification. Due to the strong influence of the Russian school of pedology 
in Serbia, saline soils here are typically classified within two general groups: solonetz and solonchak. Recent investigations confirm that in the Vojvodina region, the primary saline soils fall within the solonchak and solonetz categories. The main characteristics of solonetz and solonchak are summarized in Table 1.

Table 1. Main characteristics of solonetz and solonchak soils in Vojvodina.

\begin{tabular}{|c|c|}
\hline Soil Type & Main Characteristics \\
\hline Solonchak & $\begin{array}{l}\text { Salt content usually ranging } 0.15-0.25 \% \text { in } \mathrm{Bt} \text { horizon. } \\
\text { Characterized by relatively shallow surface } \mathrm{A} / \mathrm{E} \text { horizon and a thick } \mathrm{Bt} \\
\text { horizon with over } 15 \% \text { of adsorbed sodium ions }(\mathrm{Na}+\text { ). } \\
\text { The surface A/E horizon has a weakly acidic } \mathrm{pH} \text { reaction, as a result of } \\
\text { leaching of carbonates and water-soluble salts. } \\
\text { Occupy the surface of } 75,000 \text { ha in the Vojvodina Region. } \\
\text { Containing at least } 1 \% \text { of salt (chloride and sulfate salinization) or more } \\
\text { than } 0.7 \% \text { (sodic salinization), in any horizon up to } 125 \mathrm{~cm} \text { of depth. } \\
\text { The internal morphology is often structured as Asa/E-Bt-BtC and as } \\
\text { Asa-AC-C. } \\
\text { High alkaline pH values of soil in all horizons due to the intensive } \\
\text { alkalinization process. } \\
\text { Characterized by extremely low microbiological activity and the low } \\
\text { number of individual groups of microorganisms in the surface saline } \\
\text { layer. } \\
\text { Occupy the surface of } 15,000-25,000 \text { ha in the Vojvodina Region. }\end{array}$ \\
\hline
\end{tabular}

All solonetz and the vast majority of solonchaks in Serbia have horizonation of A/E$\mathrm{Bt}-\mathrm{BtC}$ and have generally formed in either alluvium or loess deposits. The soil depth in solonchak soils is usually limited by a high water table, with high salt content (Figure 2).

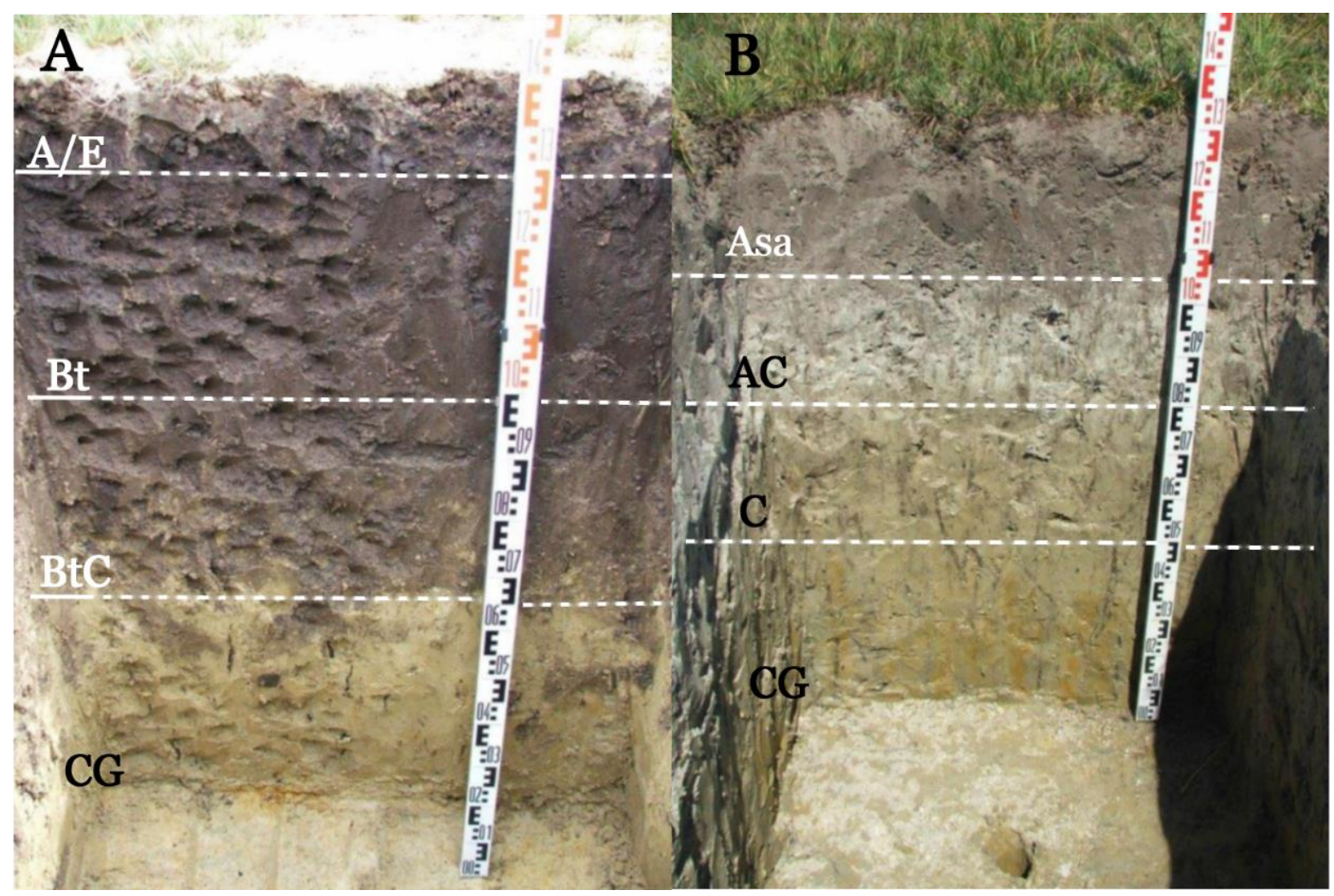

Figure 2. Internal morphology of a solonetz (A) and a solonchak (B) soil in the Vojvodina region. The highest salt concentrations are present in A/E soil horizons. Photos by Jovica Vasin. 
Saline soils are important as habitats for highly specialized vegetation communities. This abiotic-biotic coupling creates a characteristic slatina landscape (Figures 3 and 4).

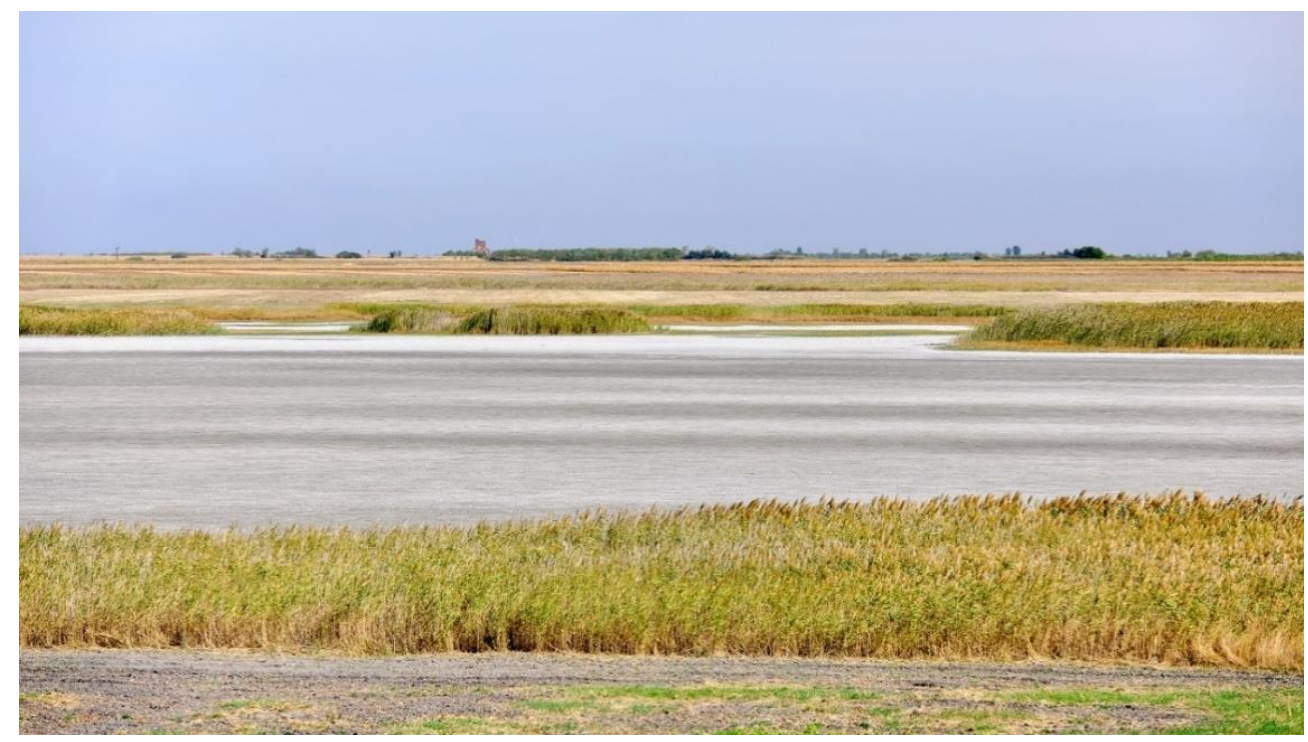

Figure 3. The slatina landscape at the Slano Kopovo locality, showing saline soils as patches of white. Intervening area with vegetation also have less-salty but still saline soils. Photo by Lazar Lazić.

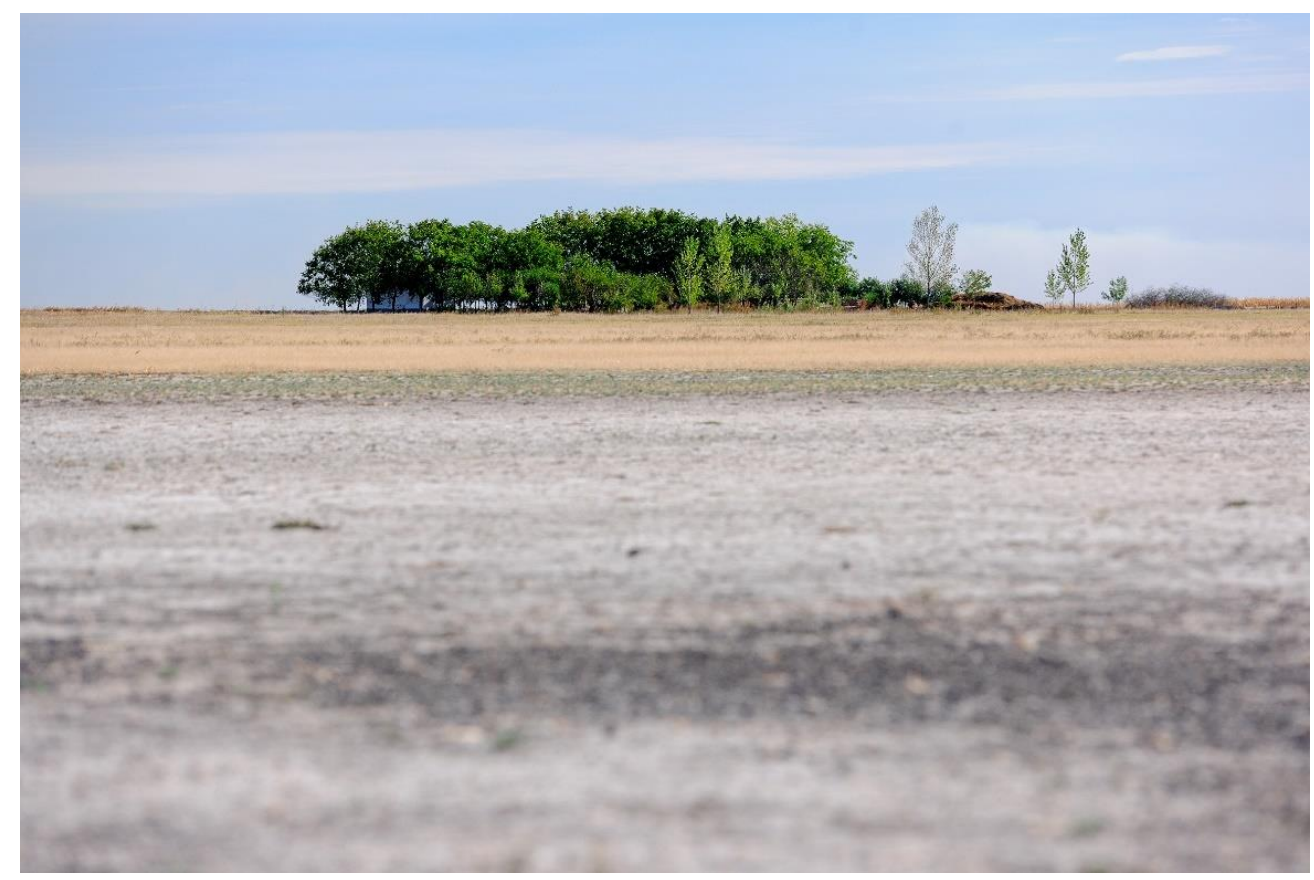

Figure 4. The slatina landscape at the Slano Kopovo locality. Note the white salt crust on the soil surface, and the general lack of macrovegetation. Photo by Lazar Lazić.

Halomorphic vegetation has clear endemic characteristics. For example, succulent plants like Salicornia europea L. (Figure 5) Slano Kopovo is the only remaining habitat in Serbia, while Suaeda pannonica (G. Beck) Ascherson \& Graebner was confirmed at only three localities-Slano kopovo, Rusanda and Okanj bara [26]. Those two species plus Suaeda maritima (L.) Dumort. and Salsola soda L. are characterized for solonchak soils. 


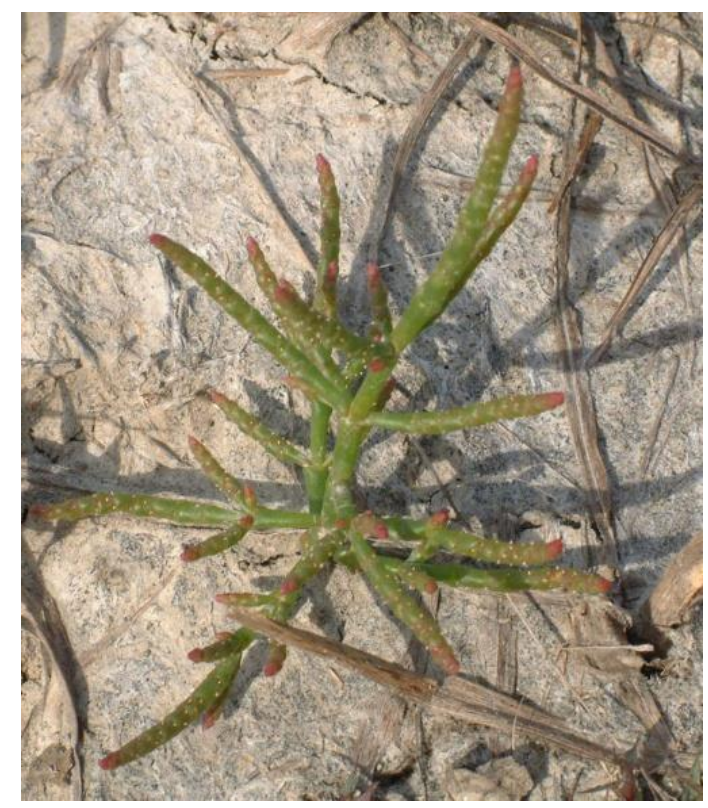

Figure 5. Salicornia europea. Photo by Dubravka Milić.

In the past, significant effort has been made to protect and preserve saline soil habitats as biologically valuable areas. Figure 6 shows that minor areas of slatina landscapes are now included in protected zones. We argue that more of these landscapes should be evaluated and protected in the future. Examples of areas currently protecting saline soils are the Special Nature Reserves Slano Kopovo and Okanj bara, as well as Nature Park Rusanda (Figures 6 and 7), which represents one of the last preserved areas with endangered ecosystems such as salt pans and marshes, as well as saline and steppic meadows with specific pannonic endemic diversity, involving primarily euhalophytic flora [26]. These protected areas also have international importance; as IBA areas (important bird area), IPA areas (important plant area), and as proposed for a NATURA 2000 area. Beside this, Slano Kopovo is a Ramsar site (wetland of international importance) and Emerald network (declared an Area of Special Conservation Importance (ASCI)).

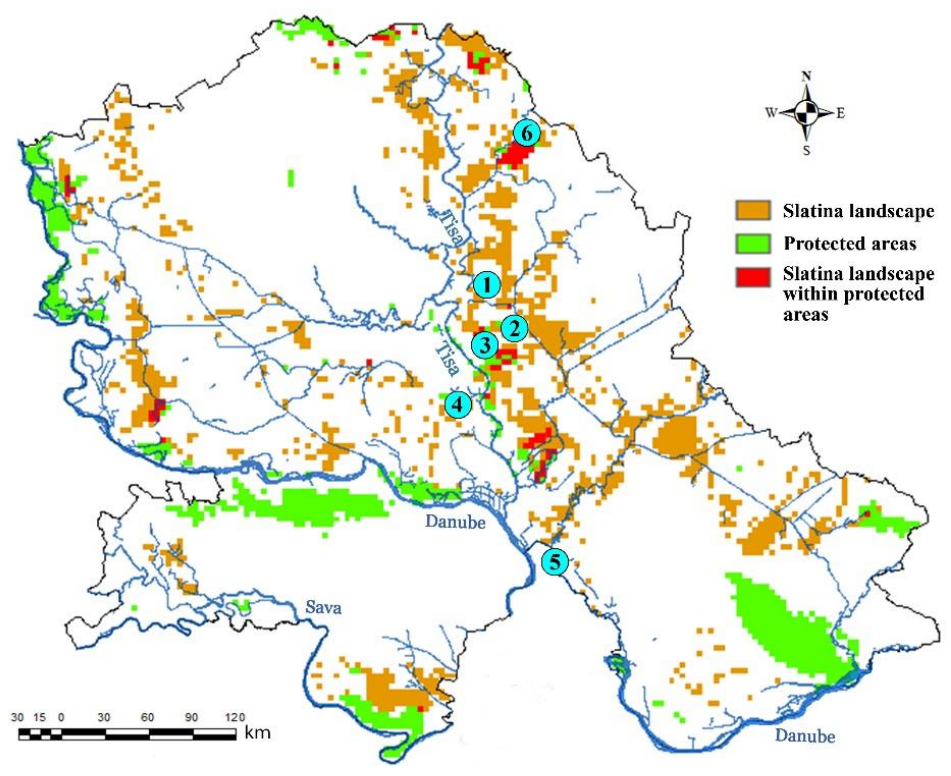

Figure 6. Map of slatina landscapes in the Vojvodina region within and outside of otherwise protected areas: (1)—Slano Kopovo, (2)—Jegrička, (3)—Rusanda, (4)—Okanj Bara, (5)—Pečena Slatina, (6)-Pašnjaci Velike Droplje. 


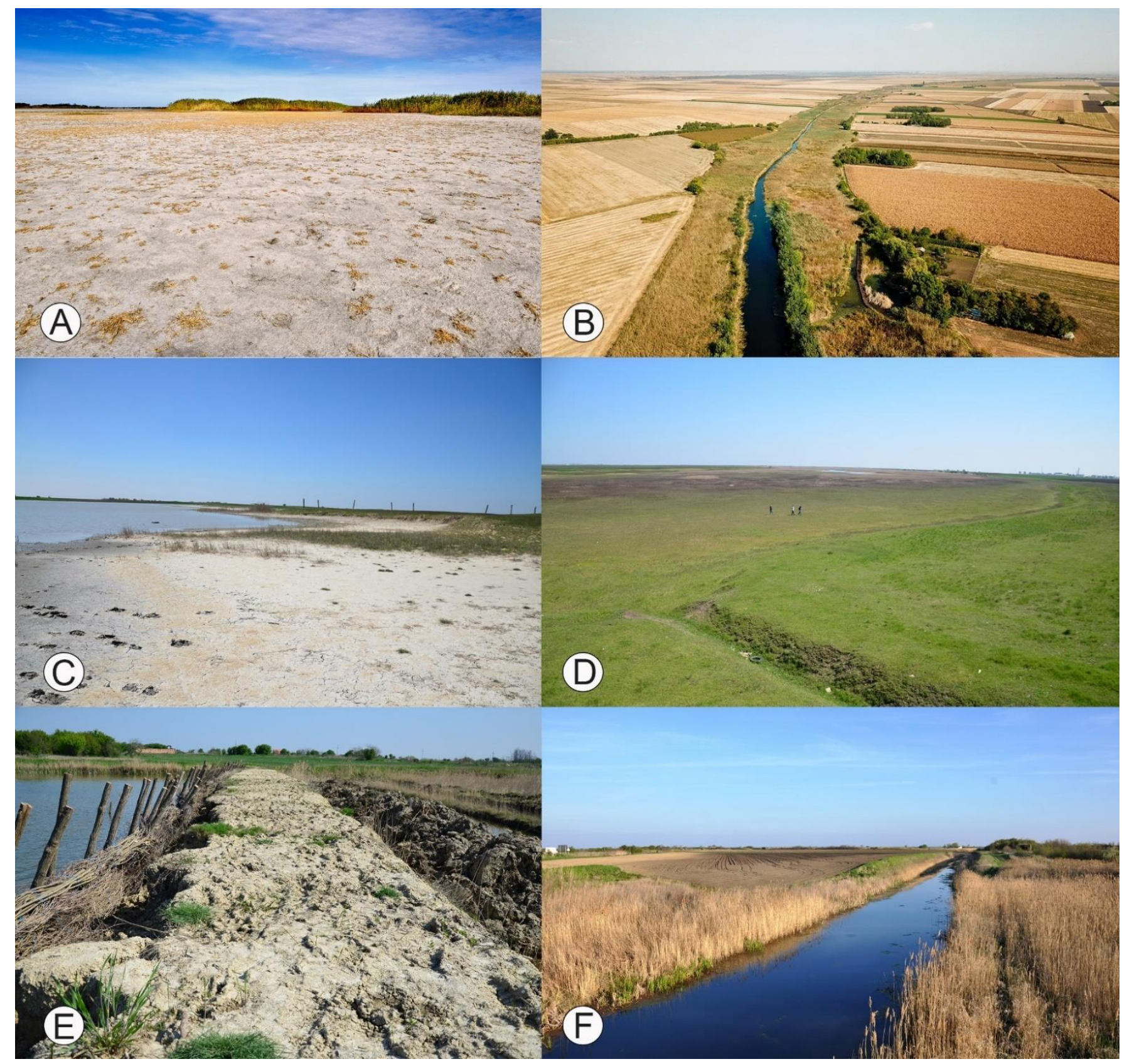

Figure 7. The various saline soil landscapes discussed in this paper (A)—Slano Kopovo, (B)—Jegrička, (C)—Rusanda, (D)—Okanj Bara, (E)—Pečena Slatina, (F)—Pašnjaci Velike Droplje. Photos by Slobodan Marković, Lazar Lazić and Tijana Đorđević.

\section{Study Area}

In this study, we selected six of the most attractive sites in the Vojvodina region: Jegrička, Slano Kopovo, Rusanda, Okanj, Pečena slatina, and Pašnjaci Velike Droplje (Figures 6 and 7).

Slano Kopovo is located at the northern part of the Vojvodina region, between regional roads Novi Bečej-Novo Miloševo-Kikinda and Novi Bečej-Bašaid (Figure 6(1). The saline soils here have been preserved in paleomeander on a terrace of Tisa River $[27,28]$. This relict fluvial landform is worthy of the attention of a variety of natural science scholars, as well as other types of visitors (Figures 3, 4 and 7). Until now, Slano Kopovo was mostly known as an important ornithological site, protected as a Ramsar wetland habitat (https:/ / www.ramsar.org/, accessed on 25 March 2021). However, geomorphological, hydrological, pedological and other biological characteristics of this Special Nature Reserve also have 
great potential for ecotourism. Particularly interesting is the experience during the summer dry season, when the shallow surface water evaporates and the basin becomes completely white with salts, contrasting well with the surrounding green to yellow agricultural fields. We regard this site as an ideal interpretative example of the soil salinization process. Slano Kopovo is also famous due to its unusual atmospheric effects, such as Fata Morgana (superior mirage) and local turbulent air circulation $[29,30]$.

The Jegrička River basin covers $\approx 60,000$ ha in the central part of the Vojvodina region (Figure 7B). Large paleomeanders associated with the Jegrička River indicate that they are relict features from the last glacial (paleo-Danube) channel. The original Jegrička watercourse has become an integral part of a complex canal network of the multi-functional Danube-Tisa-Danube hydro-system. Jegrička has a conductive regime, notably in the upper and middle parts, where its bed is partly regulated. The length of the watercourse is approximately $65 \mathrm{~km}$, with a mild longitudinal fall of approximately $4-5 \mathrm{~cm} / \mathrm{km}$. The channel width varies in the range of $2-3 \mathrm{~m}$ (in the upper part) to $>100 \mathrm{~m}$, where the watercourse spills over the surrounding natural depressions and becomes stagnant in wetland areas. The water depth in most watercourse sections is in the range of 1-2 $\mathrm{m}$, and therefore, the gravity inflow into Tisa River is supported by a pumping station with a capacity of $2.0 \times 8.0 \mathrm{~m}^{3} / \mathrm{s}$ [31].

In this study we focus on the saline soil landscape in Jegrička valley between Žabalj on the west and Tisa River in the east. Here, the Jegrička River has been transformed into a fish pond near the regional road Novi Sad-Zrenjanin.

Rusanda (or Velika Rusanda) is one of the largest alkaline salt lakes in Serbia (Figure 7C). It is located in the central part of the Vojvodina region, near western side of Melenci settlement, $16.5 \mathrm{~km}$ northwest of the City of Zrenjanin. Like Slano Kopovo, this site also has formed in a paleomeander of a Tisa River terrace [27,28]. The lake at Rusanda has, therefore, slightly elongated and curved shape (Figure 7). It is a shallow, semistatic water body with a maximum depth of less than $1.5 \mathrm{~m}$, which is achieved during the spring season. The approximate aquatoria of Lake Rusanda is $1.5 \mathrm{~km}^{2}$. The noteworthy characteristic of this lake is its muddy springs on the lake bed. Unlike most freshwater lakes, this saline lake is a closed system (without outflow) fed by surface inflow (runoff), direct precipitation and different ground water sources including the upflow of abyssal waters [32].

Spa "Rusanda" is the rehabilitation resort located on the northern shore of Lake Rusanda, in the Melenci settlement. Since it was founded in 1867, the spa has had a reputation for rehabilitation, based on the assumed healing properties of the mineral peloide (mud), extracted from the lake. Local peoples believe that thus mud is one of the best in the country for its healing properties. The bottom of the lake is covered in an extremely pure, non-organic mud, the scent of which resembles sulfore-hydrate. The lake's water is like sea water-high in salt and alkaline. The spa also hosts a thermal, mineral water well, with a water temperature of $32^{\circ} \mathrm{C}$. The thermal water, classified as having sodium hydro-carbonate sulfide hemotherms, is used for hydro-therapeutic purposes [33]. Development of the geotouristic site will further enhance the existing tourist appeal of this specific destination.

Several other paleomeanders, located between Taraš, Kumane, Melenci and Elemir settlements, are preserved on the terrace of Tisa River [27,28]. Okanj bara represents one of the last preserved areas, with its endangered ecosystems of salt pans and marshes, and steppe meadows with endemic Pannonian biodiversity that includes primarily euhalophytic flora, rare insects, amphibians, birds and mammals (Figure 7D). Because of its natural values, the Institute for Nature Conservation of Serbia proposed in 2008 that Okanj bara be set aside for protection as an exceptionally significant natural domain [26]. Okanj, Čikoš and Crvenka lakes, as well as several former Tisa river channels, represent good examples of different stages in development of several generations of paleomeanders [27].

Pečena Slatina and Slatina are also within paleomeanders of the former Tisa River and these sites are currently situated in the Tamiš River valley (Figure 7E). During the Holocene, the Tisa River shifted its channel westward, significantly prolonging the length 
of the Tamiš River and moving the confluence towards the Danube River. Thus, in this area one can find a wide diversity of fluvial landforms, such as point bars, meanders, and fossil river channels [29]. These meanders are located in the southern part of the Vojvodina region, near the western margin of Baranda settlement (Figures 6 and 7). Fužinato et al. [34] reported on the occurrence of some cyanobacteria in salty puddles in Pečena Slatina and Slatina localities, which previously were only known to exist in tropical regions in Africa and Asia. The species identified typically inhabit of salty alkaline lakes in Africa, indicating the unique environmental conditions of the Pečena Slatina site. Slatina lake is partly used as a fish pond. These lakes are also well-known ornithological sites. During the last several years, the owners of the local fishpond began to promote ecotourism at Pečena Slatina and Slatina, as potential attractive ecotourist destinations.

Special Nature Reserve Pašnjaci velike droplje (Figure 7F) contains a unique mosaic of different lowland landscapes and is the only habitat of the Great Bustard (Otis tarda) in Serbia [35]. The reserve is in the northern part of the Vojvodina region, on the alluvial plane of the Zlatica River, east of the City of Kikinda. The Zlatica River most likely represents an abandoned channel of the Paleo Moros River, given that the Zlatica River could not have formed its current alluvial plain [27,36]. The diverse fluvial geomorphology of the site has led to the formation of many different, mostly grassland, ecosystems on saline soils of low agricultural productivity. Development of ecotourism here is primarily based on endangered birds, its heterogeneous fauna, which has been integrated into an educational theme. Possibilities also exist at this site for organizing photo safaris, as well as voluntary and educational camps [37]. Additional touristic values can be derived from the interpretation of interactions between abiotic and biotic natural processes, especially the relationship between pedogenesis of saline soils and endemic halophytic vegetation.

\section{Methodology}

In order to assess the six sites mentioned above, and evaluate their current state and tourism potential, we propose a novel approach for the assessment of saline soil sites. This new methodology has its roots in previous assessment models and studies, all mainly related to resources such as geoheritage [4,38-42], spas and hot springs [43] and cultural heheritage [44-48], and their use for tourism. These methods have been succesfully applied numerous times in the assessment of various geosites [49-68], spas [43,69-71], and sites of cultural heritage $[44,47,48]$. The majority of tourism related subindicators were derived from these existing models and been adapted in this study for saline soil assessment, while the subindicators Geomorphological attractiveness, Pedodiversity, Biodiversity, Endemic and relict plant species and Ambience were introduced by the authors of this paper, based on the opinion of experts. Eight tourism and soil experts (researchers and professors from these fields of expertise) were asked to suggest the subindicators they consider important for the assessment of the current state and tourism potential of soil sites. These subindicators proved to be essential when assessing the tourist potential of saline soil sites, because they affect the quality of the tourist experience. The complete subindicator list and structure of the model are presented in Table 2.

Table 2. The structure of the soil site assessment model.

\begin{tabular}{|c|c|}
\hline Indicators/Subindicators & Description \\
\hline \multicolumn{2}{|l|}{ Main values $(\mathrm{MV})$} \\
\hline 1. Rarity & Number of sites nearby with similar overall characteristics \\
\hline $\begin{array}{l}\text { 2. Possibilities for } \\
\text { interpretation and } \\
\text { education }\end{array}$ & Level of interpretive possibilities on pedological processes and pedogenesis \\
\hline $\begin{array}{l}\text { 3. Geomorphological } \\
\text { attractiveness }\end{array}$ & Number of existing micro-landforms (meanders, point bars, old river valleys, etc.) \\
\hline
\end{tabular}


Table 2. Cont.

\begin{tabular}{|c|c|c|}
\hline \multicolumn{2}{|c|}{ Indicators/Subindicators } & \multirow[t]{2}{*}{ Description } \\
\hline \multicolumn{2}{|c|}{ Main values (MV) } & \\
\hline 4. & Pedodiversity & Number of different soil types and varieties \\
\hline 5. & Biodiversity & $\begin{array}{l}\text { Number of different vascular plant and bird species (must inhabit the site for at least a part of the } \\
\text { year) }\end{array}$ \\
\hline 6. & $\begin{array}{l}\text { Endemic and relict } \\
\text { plant species }\end{array}$ & $\begin{array}{l}\text { Total number of endemic and relict plant species as well as those included in the world red list of } \\
\text { threatened species and the red list of Serbian flora. }\end{array}$ \\
\hline 7. & Ambience & $\begin{array}{l}\text { The character of the site as it relates to its visual experience for potential visitors-contrast of colors, } \\
\text { appearance of shapes, etc. }\end{array}$ \\
\hline 8. & $\begin{array}{l}\text { Surrounding } \\
\text { landscape and } \\
\text { nature }\end{array}$ & $\begin{array}{l}\text { Panoramic view quality, presence of water and vegetation, absence of human-induced deterioration, } \\
\text { vicinity of urban areas, etc. }\end{array}$ \\
\hline 9. & Therapeutical value & $\begin{array}{l}\text { Therapeutical value of the soil (related to perceived utility as a treatment of medical conditions and } \\
\text { how often it is used for such purposes). }\end{array}$ \\
\hline 10. & Protection level & Protected status by local or regional groups, national government, international organizations, etc. \\
\hline 11. & Vulnerability & Vulnerability level of soils (their risks from natural processes and anthropogenic influences) \\
\hline 12. & $\begin{array}{l}\text { Suitable number of } \\
\text { visitors }\end{array}$ & $\begin{array}{l}\text { Proposed number of visitors that can sustainably utilize the site at the same time, based onsurface } \\
\text { area, vulnerability, and the current state of the site }\end{array}$ \\
\hline \multicolumn{3}{|c|}{ Tourist values (TV) } \\
\hline 13. & Accessibility & Ease with which the site can be reached \\
\hline 14. & $\begin{array}{l}\text { Additional natural } \\
\text { values }\end{array}$ & Number of additional natural values (within a radius of $5 \mathrm{~km}$ ) \\
\hline 15. & $\begin{array}{l}\text { Additional } \\
\text { anthropogenic } \\
\text { values }\end{array}$ & Number of additional anthropogenic values (within a radius of $5 \mathrm{~km}$ ) \\
\hline 16. & Promotion & Level and number of promotional resources \\
\hline 17. & Organized visits & Annual number of organized visits to the site \\
\hline 18. & $\begin{array}{l}\text { Vicinity of visitor's } \\
\text { centers }\end{array}$ & Closeness of visitor center to the site \\
\hline 19. & Interpretative panels & $\begin{array}{l}\text { Interpretative characteristics and value of text and graphics, material quality, planel size, suitability to } \\
\text { surroundings, etc. }\end{array}$ \\
\hline 20. & Number of visitors & Annual number of visitors \\
\hline 21. & $\begin{array}{l}\text { Tourism } \\
\text { infrastructure }\end{array}$ & $\begin{array}{l}\text { Level of additional infrastructure for tourists such as pedestrian pathways, resting places, garbage } \\
\text { cans, toilets etc. }\end{array}$ \\
\hline 22. & Tour guide service & $\begin{array}{l}\text { If local expertise exists, the level, knowledge of foreign language(s), interpretative skills, etc. of the } \\
\text { experts }\end{array}$ \\
\hline 23. & Hostelry service & Hostelry services close to the site \\
\hline 24. & Restaurant service & Restaurant services close to the site \\
\hline
\end{tabular}


Table 2. Cont.

\begin{tabular}{|c|c|c|c|c|c|}
\hline \multicolumn{2}{|c|}{ Indicators/Subindicators } & \multicolumn{4}{|c|}{ Description } \\
\hline \multicolumn{6}{|c|}{ Grades (1-5) } \\
\hline & 1 & 2 & 3 & 4 & 5 \\
\hline 1. & Common & Regional & National & International & The only occurrence \\
\hline 2. & None & $\begin{array}{l}\text { Moderate level of } \\
\text { processes, difficult to } \\
\text { explain to non-experts }\end{array}$ & $\begin{array}{c}\text { Good example of } \\
\text { processes but difficult } \\
\text { to explain to } \\
\text { non-experts }\end{array}$ & $\begin{array}{l}\text { Moderate level of } \\
\text { processes but easy to } \\
\text { explain to a common } \\
\text { visitor }\end{array}$ & $\begin{array}{c}\text { Good example of } \\
\text { processes and easy to } \\
\text { explain to a common } \\
\text { visitor }\end{array}$ \\
\hline 3. & 1 & - & $2-3$ & - & More than 3 \\
\hline 4. & $\begin{array}{c}1-2 \\
\text { types/varieties }\end{array}$ & 3-4 types/varieties & 5-6 types/varieties & $7-8$ types/varieties & More than 8 \\
\hline 5. & $\begin{array}{l}\text { Up to } 100 \\
\text { species }\end{array}$ & $101-150$ species & 151-200 species & 201-300 species & More than 300 species \\
\hline 6. & $\begin{array}{c}1 \text { or } 2 \\
\text { species }\end{array}$ & 3-4 species & $5-6$ species & 7-8 species & More than 8 species \\
\hline 7. & - & Low & Medium & High & Exceptional \\
\hline 8. & - & Low & Medium & High & Exceptional \\
\hline 9. & $\begin{array}{l}\text { Not used } \\
\quad \text { for } \\
\text { treatment }\end{array}$ & $\begin{array}{l}\text { Occasionally used for } \\
\text { treatment by the locals }\end{array}$ & $\begin{array}{l}\text { Often used for } \\
\text { treatment by the locals }\end{array}$ & $\begin{array}{l}\text { Intensively used for } \\
\text { treatment by the locals }\end{array}$ & $\begin{array}{l}\text { Organized treatment } \\
\text { in the form of a spa }\end{array}$ \\
\hline 10. & None & Local & Regional & National & International \\
\hline 11. & $\begin{array}{l}\text { Irreversible } \\
\text { (with } \\
\text { possibility } \\
\text { of total } \\
\text { loss) }\end{array}$ & $\begin{array}{l}\text { High (could be easily } \\
\text { damaged) }\end{array}$ & $\begin{array}{l}\text { Medium (could be } \\
\text { damaged by natural } \\
\text { processes or human } \\
\text { activities) }\end{array}$ & $\begin{array}{l}\text { Low (could be } \\
\text { damaged only by } \\
\text { human activities) }\end{array}$ & None \\
\hline 12. & 0 & 0 to 10 & 10 to 20 & 20 to 50 & More than 50 \\
\hline 13. & Inaccessible & $\begin{array}{l}\text { Low (on foot with } \\
\text { special equipment and } \\
\text { expert guide tours) }\end{array}$ & $\begin{array}{l}\text { Medium (by bicycle } \\
\text { and other means of } \\
\text { man-powered } \\
\text { transport) }\end{array}$ & High (by car) & Utmost (by bus) \\
\hline 14. & None & 1 & 2 to 3 & 4 to 6 & More than 6 \\
\hline 15. & None & 1 & 2 to 3 & 4 to 6 & More than 6 \\
\hline 16. & None & Local & Regional & National & International \\
\hline 17. & None & Less than 10 per year & $11-12$ per year & 13-14 per year & More than 14 per year \\
\hline 18. & $\begin{array}{l}\text { More than } \\
50 \mathrm{~km}\end{array}$ & 50 to $20 \mathrm{~km}$ & 20 to $5 \mathrm{~km}$ & 5 to $1 \mathrm{~km}$ & Less than $1 \mathrm{~km}$ \\
\hline 19. & None & Low quality & Medium quality & High quality & Utmost quality \\
\hline 20. & None & Low (less than 100) & Medium (101 to 150) & High (151 to 200) & $\begin{array}{l}\text { Utmost (more than } \\
\text { 200) }\end{array}$ \\
\hline 21. & None & Low & Medium & High & Utmost \\
\hline 22. & None & Low & Medium & High & Utmost \\
\hline 23. & $\begin{array}{l}\text { More than } \\
50 \mathrm{~km}\end{array}$ & $25-50 \mathrm{~km}$ & $10-25 \mathrm{~km}$ & $5-10 \mathrm{~km}$ & Less than $5 \mathrm{~km}$ \\
\hline 24. & $\begin{array}{l}\text { More than } \\
25 \mathrm{~km}\end{array}$ & $10-25 \mathrm{~km}$ & $10-5 \mathrm{~km}$ & $1-5 \mathrm{~km}$ & Less than $1 \mathrm{~km}$ \\
\hline
\end{tabular}

Our methodology consists of two groups of indicators: Main Values (MV) of the soils and Tourist Values (TV). Each of these groups consists of 12 different subindicators, yielding 24 subindicators in the model which are fully listed and described in Table 2.

In the assessment process, every subindicator was rated by experts on a 5-point likert scale, with each subindicator given a value from 1 to 5 . These values and how they are rated are explained in more detail in Table 2. Upon the rating of each subindicator, the values are added up separately, first the 12 subindicators from the Main Values (MV) group, and then the 12 subindicators from the Tourist Values (TV) group. Finally, the sum of Main Values and the Tourist Values are added together. The results are presented in a matrix (Figure 8) which consists of Main Values axis (X) anda Tourist Values axis (Y). The matrix is divided into nine fields and each analyzed site is then placed into one of the 
fields, depending on the additive score of its Main Values (MV) and Tourist Values (TV). For example, if the sum of Main Values is 27 and of Tourist Values is 47, the analyzed soil site would be in the $S_{23}$ field of the matrix, indicating a medium level on Main Values and a high level on Tourist Values.

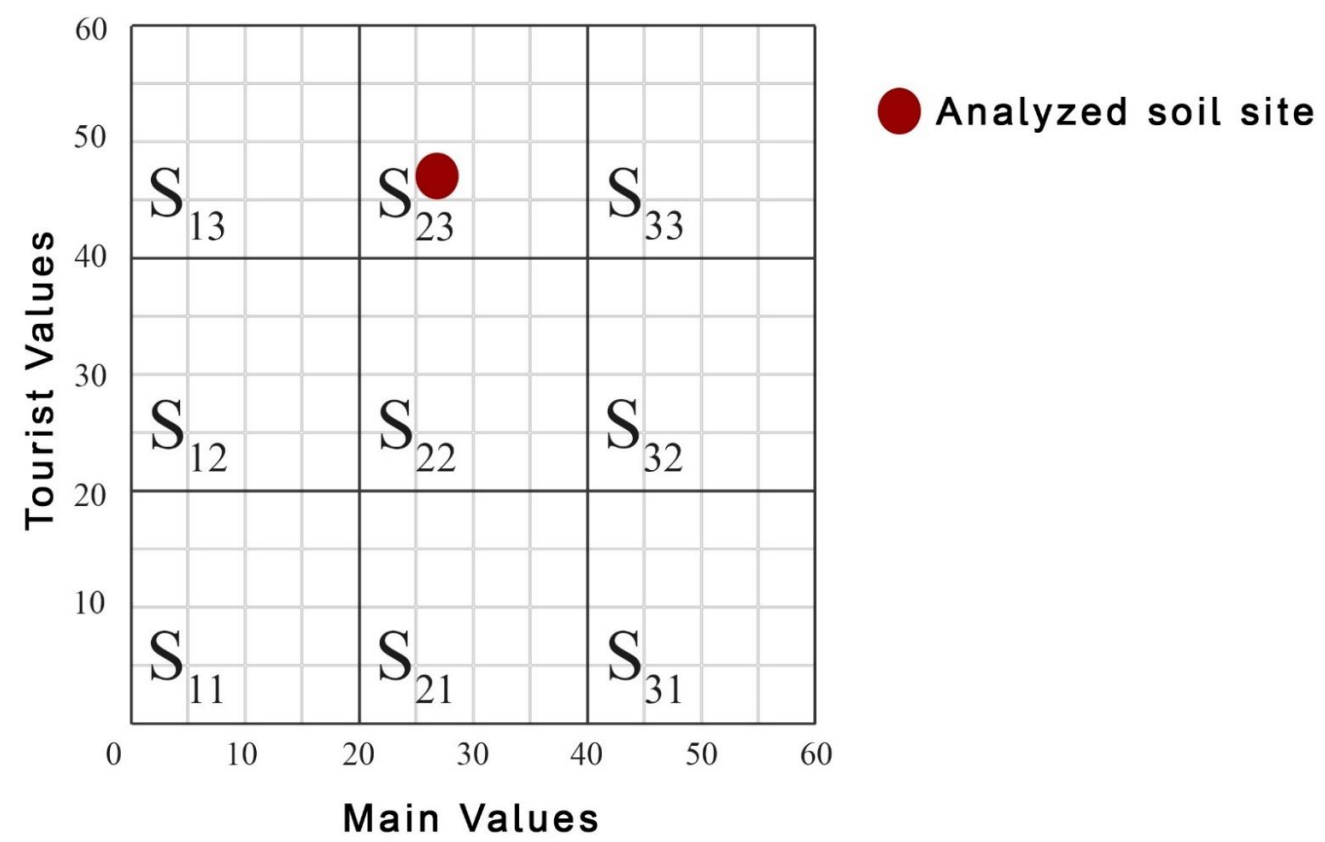

Figure 8. Example of the soil site assessment matrix and its axis variables.

\section{Results and Disscussion}

The assessment results of the six saline soil sites are shown in Table 3 and Figure 9. The Slano Kopovo saline soil site stands out significantly above the other sites, with the highest Main Values (56). Jegrička and Rusanda are tied at second place with a score of 45 for Main Values while Pečena Slatina has one point less (44). The lowest score of Main Values belongs to Okanj Bara and Pašnjaci Velike Droplje, which are tied at 42.

A further analysis of the Main Values of all sites shows that Slano Kopovo has almost the maximum scores. The only subindicators within this group with below maximum values are Surrounding landscape and nature, Therapeutical value, and Vulnerability. Based on these results, it is evident that this site possesses all the necessary natural values for high value tourism. Its high "nature-related" values make it the most suitable site for future tourism development and promotion. However, these natural values need to be accompanied by high Tourist Values as well, in order to have a robust and complete tourism product that would attract a large number of tourists.

Regarding the subindicator related to the possibilities for interpretation and education, almost all the analyzed sites have high scores (4 or 5). Only Pašnjaci Velike Droplje and Okanj Bara have lower scores (3 and 2). Another important element for tourism is the aesthetic value of a site or destination, which are evaluated using the subindicators Ambience and Surrounding landscape and nature. As can be seen in Table . , 5 out of 6 of the analyzed sites have a high value (4) for the Ambience variable. Slano Kopovo stands out, however, with the highest value (5) for this subindicator. With regard to surrounding landscape, Jegrička has the highest value, while Slano Kopovo has a value of 4. Furthermore, looking at the protection level of each site, it can be noticed that only Slano Kopovo is protected on an international level, given that it is a Ramsar wetland. Most of the other sites are protected on a national level; Pečena Slatina remains unprotected on a national level. 
Table 3. Subindicator values, as applied by experts, for each site.

\begin{tabular}{|c|c|c|c|c|c|c|}
\hline \multicolumn{7}{|c|}{ Values Given by Experts (1-5) } \\
\hline & SS1 & SS2 & SS3 & SS4 & SS5 & SS6 \\
\hline Main Values (MV) & 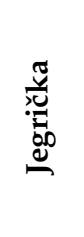 & 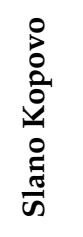 & $\begin{array}{l}\underset{\widetilde{J}}{\Xi} \\
\underset{\nexists}{\Xi} \\
\underset{\Xi}{\Xi}\end{array}$ & 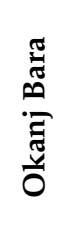 & 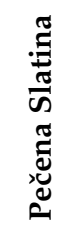 & 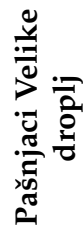 \\
\hline 1. Rarity & 3 & 5 & 4 & 3 & 4 & 3 \\
\hline $\begin{array}{l}\text { 2. Possibilities for interpretation and } \\
\text { education }\end{array}$ & 4 & 5 & 4 & 3 & 4 & 2 \\
\hline 3. Geomorphological attractiveness & 4 & 5 & 4 & 3 & 4 & 3 \\
\hline 4. Pedodiversity & 3 & 5 & 3 & 2 & 5 & 5 \\
\hline 5. Biodiversity & 4 & 5 & 3 & 4 & 3 & 4 \\
\hline $\begin{array}{l}\text { 6. Endemic and relict plant and } \\
\text { animal species }\end{array}$ & 4 & 5 & 3 & 3 & 2 & 2 \\
\hline 7. Ambience & 4 & 5 & 4 & 4 & 4 & 4 \\
\hline 8. Surrounding landscape and nature & 5 & 4 & 3 & 4 & 3 & 3 \\
\hline 9. Therapeutical value & 2 & 3 & 5 & 3 & 4 & 2 \\
\hline 10. Protection level & 4 & 5 & 4 & 4 & 3 & 4 \\
\hline 11. Vulnerability & 3 & 4 & 3 & 4 & 3 & 5 \\
\hline 12. Suitable number of visitors & 5 & 5 & 5 & 5 & 5 & 5 \\
\hline Sum of Main Values & 45 & 56 & 45 & 42 & 44 & 42 \\
\hline \multicolumn{7}{|l|}{ Tourist Values (TV) } \\
\hline 13. Accessibility & 5 & 4 & 4 & 3 & 4 & 3 \\
\hline 14. Additional natural values & 5 & 5 & 5 & 5 & 5 & 5 \\
\hline 15. Additional anthropogenic values & 5 & 5 & 5 & 5 & 5 & 5 \\
\hline 16. Promotion & 2 & 5 & 3 & 2 & 2 & 3 \\
\hline 17. Organized visits & 5 & 5 & 5 & 4 & 4 & 3 \\
\hline 18. Vicinity of visitor's centers & 5 & 5 & 3 & 3 & 2 & 5 \\
\hline 19. Interpretative panels & 3 & 5 & 5 & 5 & 3 & 4 \\
\hline 20. Number of visitors & 5 & 5 & 5 & 4 & 4 & 4 \\
\hline 21. Tourism infrastructure & 4 & 4 & 5 & 3 & 3 & 3 \\
\hline 22. Tour guide service & 4 & 4 & 4 & 2 & 2 & 2 \\
\hline 23. Hostelry service & 5 & 3 & 5 & 2 & 4 & 3 \\
\hline 24. Restaurant service & 5 & 3 & 5 & 2 & 4 & 3 \\
\hline Sum of Tourist Values & 53 & 53 & 54 & 40 & 42 & 43 \\
\hline
\end{tabular}

The therapeutical and healing properties of soil and mud in a certain area are often linked to an increase in visitor numbers. When it comes to our sites, Rusanda has the longest tradition of utilizing this type of resource. It is the only site that has a spa where mud is regularly used for healing purposes. At the other sites, such mud is also used, however to a less extent than at Rusanda.

One of the elements that also attracts many visitors to these types of destinations is the biodiversity, particularly the number of rare bird and plant species. Once again, Slano Kopovo has the highest score among the analyzed sites. It possesses remarkable biocenological characteristics and it is recognizable by the specific brinish communities of the Tero-Salicornietea class. The features of the microrelief, together with the mutual dependence of ground moisture and salinity, are reflected in the nature of the ecological row of communities and in the flora. Plant species here are mostly annual succulent halophytes. The species Suaeda pannonica is a Pannonian endemic species and is on the Red List of Serbian Flora as well as Common Glasswort (Salicornia europaea) and they both are critically endangered taxon. Another endemic species is the Schwarzenberg's Plantain (Plantago schwarzenbergiana) which is a Transylvanian-Pannonian species from 
the World Red List of Plants. Besides its diverse flora, this site has 210 bird species (63\% of the total number of known species in the Vojvodina region) and 25 species of mammals, such as the Slender-billed Curlew (Numenius tenuirostris), the Red-breasted goose (Branta rufcollis) and the Imperial Eagle (Aquila heliaca) [72]. During the migration period in the autumn, here in Slano Kopovo about 20,000 grey cranes (Grus grus) can gather in just one moment [73]. The sites of Jegrička, Okanj Bara and Pašnjaci Velike Droplje have a slightly lower biodiversity values (4), but still rank high enough to appeal to certain tourism market segments. Jegrička has three species coded as strictly protected by a national legal act (Code on declaration and protection of strictly protected and protected wild species of plants, animals and fungi ("Official Gazette of RS", no. 5/2010)): the Marsh Fern (Thelypteris palustris), White Water Lilly (Nymphaea alba) and North Africa grass (Ventenata dubia), while two species (Salvinia natans and Trapa natans) are in Apendix I of Bern Convention as strictly protected.

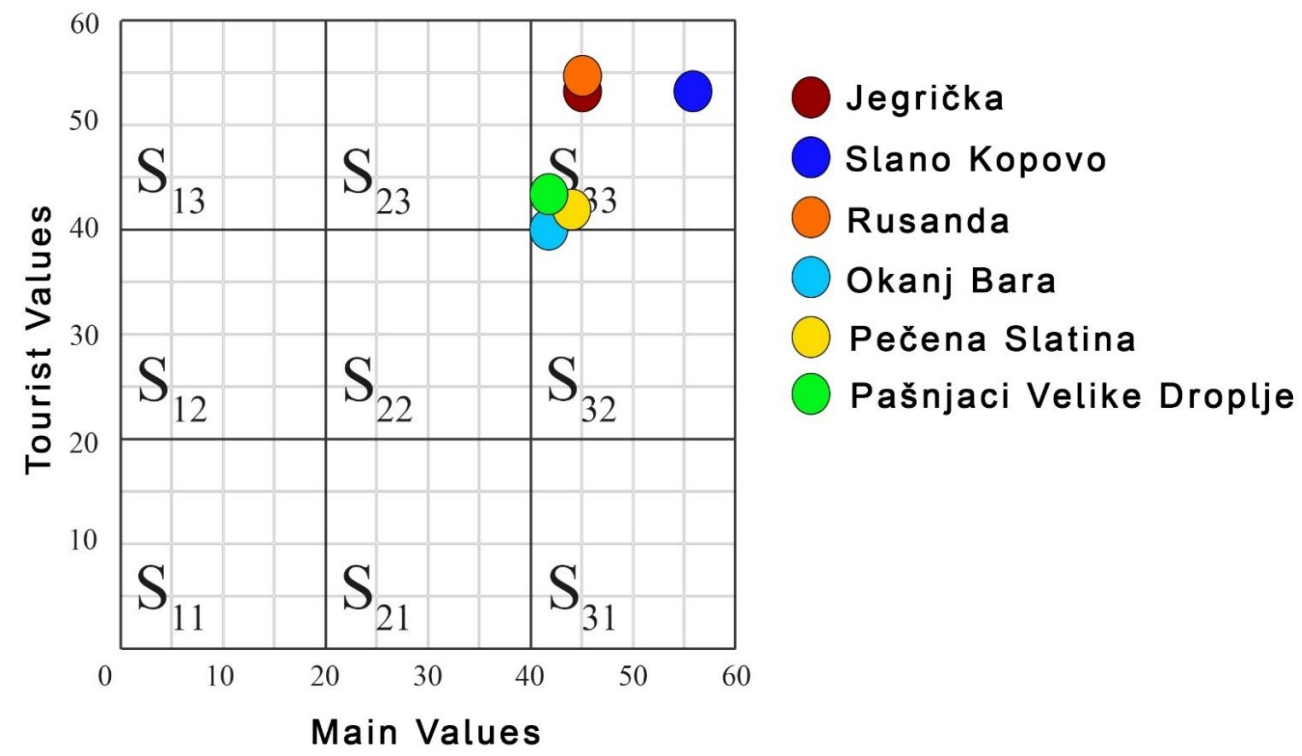

Figure 9. Position of the analyzed sites in the soil site assessment matrix.

Based on the presence of a great number of species of international importance, in 2005, the area was proclaimed as an IPA area. The site Okanj Bara also has several Pannonian endemic plant species, such as Limonium gmelini, Plantago schwarzenbergiana and subendemic species (Pucinellia distans ssp. limosa, Roripa sylvestris ssp. kerneri). Pašnjaci Velike Droplje is best known for its Great Bustard bird habitat. Additionally, there are also many rare plant species, especially endemic species like Schwarzenberg's plantain (Plantago schwarzenbergiana), Sadler's bachelor button (Centaurea cyanus), and also the White Sticky Catchfly (Silene viscosa), found only in a few places in North and Middle Banat. Because of its limited aerial, it is one of the most significant of the protected plant species in the Great Bustard habitat [72].

Another element that was assessed in our study was pedodiversity. For this assessment, an area of 3000 square meters was considered. The data was based on the pedological maps of the Military Geographical Institute of Serbia. The sites of Slano Kopovo, Pečena Slatina and Pašnjaci Velike Droplje have the highest pedodiversity and have thus obtained the maximum score of 5 . The soils that are present here mostly belong to the following types (and their varieties): Solonetz, Solonchak, Antraquic Gleysol (Eugley), Mollic and Haplic Gleysol, Chernozem, and Fluvisol.

Regarding Tourist Values, the analyzed sites can be categorized into two groups. The first group includes Jegrička, Slano Kopovo and Rusanda, which have very similar scores. Rusanda has a slight overall advantage with a score of 54, while Slano Kopovo and Jegrička have scores of 53. The second group includes the remaining three sites, with Pašnjaci Velike 
Droplje having a slight advantage with a score of 43 (Okanj Bara is at (40) and Pečena Slatina is at (42)).

Most of the sites are accessible by car or bus; Pašnjaci Velike Droplje and Okanj Bara are partially accessible by car and require some walking $(\approx 500 \mathrm{~m})$. All of the sites are located within or near protected areas, so they possess additional natural values such as rivers, lakes, swamps, bird habitats, IBA areas and other protected areas. Notably, all of the sites are located within a few kilometers of smaller settlements, at which people can encounter cultural attractions such as historic monuments, ethno-houses, local gastronomy and culture.

Regarding promotional activities, apart from Slano Kopovo, none of the analyzed sites are currently being promoted at a high level. The promotional activities for most of the sites are mainly on a local or regional level.

Another important element for tourism development includes visitor centers and tour guide services. Jegrička, Slano Kopovo and Pašnjaci Velike Droplje have a visitor center in the vicinity, while the other analyzed sites do not. Because Rusanda and Okanj Bara are located near the city of Zrenjanin, the nearest visitor center dedicated to Nature Reserves in the territory of Zrenjanin is within the city. When it comes to the quality of tour guide service, only Jegrička, Slano Kopovo and Rusanda have regular tour guide service in Serbian and English; the other sites do not offer the same quality of service. Quality and multi-lingual guide service is a very important factor in the development of tourism. Tourists are often people who know little about pedological processes, so proper interpretation is required.

Besides these elements, basic tourism infrastructure is also necessary at each site. Given the fact that Rusanda is located near the Rusanda spa in Melenci, all the existing infrastructure, as well as hostelry and restaurant services are currently available. Jegrička and Slano Kopovo also have high values for the tourism infrastructure subindicator, while Okanj Bara, Pečena Slatina and Pašnjaci Velike Droplje currently lack basic tourism infrastructure, such as information boards, signs, walking paths, parking, toilets, etc. Ideally, information boards, signs and panels should provide visitors valuable information and many important and interesting facts that supplement their overall impression of the site. Such amenities should help visitors understand the ecosystem and the significance of saline soils at the sites, which will help them understand the surroundings better. Interpretive panels, in the absence of a guide, simplify complex natural processes and provide meaningful information about the soil sites. Therefore, for many of these sites, we argue that it is necessary to significantly improve the number and quality of interpretive panels, so as to increase the overall tourist experience. The other problem that these sites have involves language; most of the existing interpretive boards are written in Serbian.

Given the fact that promotional activities, infrastructure, visitor centers, interpretive panels, and tour guide services are one of the most important of human-induced amenities for successful tourism, these elements should be the primary focus of future tourism development, if the intent is to attract more visitors to the sites. Most of the sites possess high natural values. Nonetheless, besides these natural values, the human factor also plays a crucial role in tourism development and therefore more effort needs to be put towards this aspect in order to draw more visitors to the sites.

Finally, we note that the overall scores, on the Main and Tourist Value axes for the sites, add additional insight. As shown in Figure 9, Slano Kopovo, Jegrička and Rusanda fit well within the $S_{33}$ field of the data matrix, indicating that they have very high Main and Tourist Values. Slano Kopovo has the highest overall score and therefore the largest potential for tourism development. Its high score is mostly the result of high Main Values while Tourist Values still have room for improvement. Okanj Bara, Pečena Slatina and Pašnjaci Velike Droplje are in the same field but rank slightly lower. Based on these data, Slano Kopovo, Jegrička and Rusanda should be the primary focus for future tourism development, as they have a good balance of Main and Tourist values but also provide opportunities for enhanced tourist attractions. As these types of destinations are of interest for smaller 
segments of the tourism market, mainly scientists and nature lovers interested in pedology and biodiversity, significant effort should be made towards attracting other segments of the tourism market. This can initially be done by promoting the unique ambience these areas offer as well as the most significant species of flora and fauna.

The additional aim of this paper is to emphasize the tourism potential of saline soils landscapes throughout the Vojvodina region. Evaluated sites provide an excellent basis for establishing the first slatina landscape route in Serbia which requires relatively low financial inputs for creating interpretative panels, pedestrian pathways, or bicycle routes and promotion through websites and other media. However, these inputs would significantly increase the touristic attractivity of evaluated destinations which is in line with the sustainable development of rural tourism in the Vojvodina region.

\section{Conclusions}

The focus of this study was to assess and compare the current state, as well as tourism potential, of six sites in the Vojvodina region of Serbia, all of which have saline soils: Jegrička, Slano Kopovo, Rusanda, Okanj, Pečena Slatina, and Pašnjaci Velike Droplje. Overall, all analyzed sites have significant tourism potential based on both natural and tourist values. In addition to the tourism potentials, analyzed sites have high value as a natural endemic ecosystem inhabited with highly specialized plants and birds.

Our results reveal a general lack of services and infrastructure, which is normally required for tourism development and necessary to attract larger groups of tourists. The sites with the largest room for improvement are Okanj Bara, Pašnjaci Velike Droplje and Pečena Slatina. These sites possess high Main Values meaning that they have the natural resources to attract tourists, however they lack basic tourism infrastructure as well as good quality tour guide service and better promotion. Therefore, these elements should be the primary focus in future tourism development. Jegrička, Slano Kopovo and Rusanda have significantly higher Main and Tourist values but with still some room for improvement. All three sites possess basic tourism infrastructure, tour guide service and other essential elements for tourism development. However, all of these require some minor improvement to raise the tourist experience to a higher level in the future.

One of the key issues related to future tourism developed is centered on the need for high quality tour guide services, interpretation signage and materials, and other forms of basic infrastructure. Indeed, because some of these sites can be visited through self-guided tours, signage and onsite interpretative materials must be improved before tourism can be expected to grow. Additionally, promotional activities such as brochures and a better internet presence are also essential. Local, regional and national tourist organizations must also promote these areas more readily. The development of tourism in these areas would enhance the currently poor tourist offerings in this part of Vojvodina, producing positive economic results and supporting community development endeavors.

Author Contributions: Conceptualization, T.Z., N.T. and S.B.M.; methodology, N.T. and S.B.M.; investigation, T.Z., N.T. and S.B.M.; writing—original draft preparation, T.Z., N.T., S.M., J.V., R.J.S., D.M., M.B.G., M.Ž., J.N. and S.B.M.; writing-review and editing, T.Z., N.T. and S.B.M.; visualization, S.M. All authors have read and agreed to the published version of the manuscript.

Funding: This research was supported by the Ministry of Education, Science and Technological Development of the Republic of Serbia, grant numbers: 451-03-9/2021-14/200032 and 451-03-9/202114/200125, and by the Serbian Academy of Sciences and Arts (grant no. F-178). This study was also supported by the First Program of the Chinese-Serbian Developing Projects (Project title: 'A Comparative Study of Past Climate Change in the East Asian Monsoon Region and the Westerly Zone Using Multiple Timescales').

Institutional Review Board Statement: Not applicable.

Informed Consent Statement: Not applicable. 
Data Availability Statement: No new data were created of analyzed in this study. Data sharing is not applicable to this article.

Conflicts of Interest: The authors declare no conflict of interest.

\section{References}

1. Directorate-General for Research and Innovation (European Commission). Proposed Mission: Caring for Soil Is Caring for Life. Available online: https:/ / op.europa.eu/en/publication-detail/-/publication/4ebd2586-fc85-11ea-b44f-01aa75ed71a1/ (accessed on 21 April 2021).

2. FAO. World Reference Base for Soil Resources 2014, Update 2015. Available online: http:/ /www.fao.org/soils-portal/data-hub/ soil-classification/world-reference-base/en/ (accessed on 21 April 2021).

3. Bach, E.; Ramirez, K.; Fraser, T.; Wall, D. Soil biodiversity Integrates Solutions for a Sustainable Future. Sustainability 2020, 12, 2662. [CrossRef]

4. Conway, J.S. A Soil Trail?-A Case Study from Anglesey, Wales, UK. Geoheritage 2010, 2, 15-24. [CrossRef]

5. De Almeda Rengel, L.; do Carmo Oliviera Jorge, M.; Guerra, A.J.T.; Fullen, M.A. Geotourism and Soil Quality on Trails Within Conservation Units in South-East Brazil. Geoheritage 2019, 11, 1151-1161. [CrossRef]

6. Qadir, M.; Ghafoor, A.; Murtaza, G. Amelioration strategies for saline soils: A review. Land Degrad. Develop. 2000, 11, 501-521. [CrossRef]

7. Rengasamy, P. World salinization with emphasis on Australia. J. Exp. Bot. 2006, 57, 1017-1023. [CrossRef]

8. Miller, J.J.; Brierley, J.A. Solonetzic soils of Canada: Genesis, distribution, and classification. Can. J. Soil Sci. 2011, 91, 889-902. [CrossRef]

9. Food and Agriculture Organization of the United Nations (2016) Saline Soils and Their Management. 2016. Available online: http:/ / www.fao.org/3/x5871e/x5871e04.htm (accessed on 22 April 2021).

10. Gupta, R.K.; Abrol, I.P. Salt-Affected Soils: Their Reclamation and Management for Crop Production. Adv. Soil Sci. 1990, 11, 223-289.

11. Statistical Year book 2020, Statistical Office of the Republic of Serbia. Available online: https://www.stat.gov.rs/sr-cyrl/ publikacije/publication/?p=12694 (accessed on 23 April 2021).

12. Miljković, N.; Eberhard, L.D.; Ayers, D.A. Salt-affected Soils of Yugoslavia. Soil Sci. 1959, 88, 51-55. [CrossRef]

13. Miljković, N. Osnovi Pedologije; Univerzitet u Novom Sadu: Novi Sad, Serbia, 1996.

14. Petrović, M. Alkalične Bare u Okolini Sombora; Letopis Matice Srpske: Novi Sad, Serbia, 1882.

15. De Sigmond, A. The alkali soils in Hungary and their reclamation. Soil Sci. 1924, 18, 379-381. [CrossRef]

16. Sigmond, A. Report on the Genetica of Alkali Soils. Translation of the Alkali subcom Of the International Society of Soil Science; International Society of Soil Science: Budapest, Hungary, 1929; Volume A.

17. De Sigmond, A. Development of Soil Science. Soil Sci. 1935, 40, 77-87. [CrossRef]

18. Treitz, P. A Szikes Talajok Javitása, Budapest; Stádium Sajtóvállalat Részvénytársaság: Budapest, Hungary, 1924.

19. Treitz, P. The "szik" lands in the Great-Central-Plain of Hungary. In Proceedings of the Papers I-st International Congress of Soil Science, Washington, DC, USA, 13-22 June 1927; Volume V.

20. Treitz, P. Hidrológiai Kőzlemények; Hydrological Sect. of the Hungarian Geological Society: Budapest, Hungary, 1931.

21. Miljković, N. Iskorišćavanje i Popravljanje Slatina; Zadružna Knjiga: Beograd, Serbia, 1955.

22. Živković, B. Gipsovanje Sodnih Slatina u Vojvodini; Arhiv za Poljoprivredne Nauke: Belgrade, Serbia, $1954 ;$ p. 16.

23. Jovica, V. Solonchaks of Vojvodina-characteristics and contemporaryClassification. Ph.D. Thesis, University of Novi Sad, Faculty of Agriculture, Novi Sad, Serbia, 2009, unpublished work.

24. Daliakopoulos, I.N.; Tsanis, I.K.; Koutroulis, A.; Kourgialas, N.N.; Varouchakis, A.E.; Karatzas, G.P.; Ritsema, C.J. The threat of soil salinity: A European scale review. Sci. Total Environ. 2016, 573, 727-739. [CrossRef]

25. Škorić, A.; Filipovski, G.; Čirić, M. Klasifikacija Zemljišta Jugoslavije, Akademija Nauka i Umjetnisti Bosne i Hercegovine, Posebna izdanja, Knjiga LXXVII, Sarajevo; Akademija Nauka i Umjetnosti Bosne i Hercegovine: Sarajevo, Bosnia and Herzegovina, 1985.

26. Panjković, B.; Perić, R.; Stojšić, V. Okanj bara-important center of floristic and ecosystem diversity of the Tisa river basin (Serbia). Studia Univ. Vasile Goldiş Arad Ser. Ştiinţele Viętii 2011, 21, 767-772.

27. Popov, D.; Marković, S.B.; Štrbac, D. Generations of meanders in Serbian part of Tisa valley. Zb. Rad. Geogr. Inst. Jovan Cvijić SANU 2008, 58, 31-42. [CrossRef]

28. Vandenberghe, J.; Kasse, C.K.; Popov, D.; Markovic, S.B.; Vandenberghe, D.; Bohncke, S.; Gabris, G. Specifying the external impact on fluvial lowland evolution: The last glacial Tisza (Tisa) catchment in Hungary and Serbia. Quaternary 2018, 1, 14. [CrossRef]

29. Marković, S.; Kicošev, S.; Lazić, L. Relief of Tamiš river vally (Banat, Yugoslavia). Geogr. Timisiensis 1995, 4, 19-27.

30. Marković, S.; Lukač, Š.; Kicošev, S. Slano Kopovo. Zaštita Prir. 1995, 48-49, 321-326.

31. Savić, R.; Ondrasek, G.; Zemunac, R.; Kovacčić, M.B.; Kranjcec, F.; Jokanović, V.N.; Bezdan, A. Longitudinal distribution of macronutrients in the sediments of Jegricka watercourse in Vojvodina, Serbia. Sci. Total Environ. 2021, 754, 142138. [CrossRef]

32. Vidaković, D.; Krizmanić, J.; Dojčinović, B.P.; Pantelić, A.; Gavrilović, B.; Živanović, M.; Novaković, B.; Ćirić, M. Alkaline soda Lake Velika Rusanda (Serbia): The first insight into diatom diversity of this extreme saline lake. Extremophiles 2019, 23, 347-357. [CrossRef] 
33. Tomić, N.; Stojsavljević, R.; Stamenković, I.; Berić, D. The use of geothermal energy resources in the tourism industry of Vojvodina (Northern Serbia). Eur. Res. 2013, 2-3, 443-454.

34. Fužinato, S.; Fodora, A.; Subakov-Simić, G. Arthrospira fusiformis (Voronichin) Komarel et lund (Cyanoprokaryota)—A new species for Europe. Algol. Stud. 2010, 134, 17-24. [CrossRef]

35. Stojnić, N.; Puzović, S.; Habijan-Mikeš, V. Present status, threatening factors and conservation measures of great bustard (Otis tarda) in Serbia. Zaštita Prir. 2009, 60, 285-294.

36. Sipos, G.; Kiss, T. Szigetképződés és Fejlődés a Maros Határszakaszán (Island formation and development on the border section of River Maros). Vizügyi Közlemények 2003, 85, 225-238.

37. Pašić, M.; Dolinaj, D.; Stojanović, V. The importance of preservation of autochthonous biotope of Panonian Plane in the area of special nature reserve'Pašnjaci velike droplje'for education and ecotourism development. Turizam 2008, 12, 23-29. [CrossRef]

38. Pralong, J.P. A method for assessing tourist potential and use of geomorphological sites. Géomorphologie 2005, 11, 189-196. [CrossRef]

39. Serrano, E.; González-Trueba, J.J. Assessment of geomorphosites in natural protected areas: The Picos de Europa National Park (Spain). Géomorphol. Formes Process Environ. 2005, 3, 197-208. [CrossRef]

40. Reynard, E.; Fontana, G.; Kozlik, L.; Scapozza, C. A method for assessing "scientific" and "additional values" of geomorphosites. Geogr. Helv. 2007, 62, 148-158. [CrossRef]

41. Tomić, N. The potential of Lazar Canyon (Serbia) as a geotourism destination: Inventory and evaluation. Geogr. Pannonica 2011, 15, 103-112. [CrossRef]

42. Tomić, N.; Božić, S. A modified geosite assessment model (M-GAM) and its application on the Lazar Canyon area (Serbia). Int. J. Environ. Res. 2014, 8, 1041-1052.

43. Tomić, N.; Košić, K. Developing the Spa Assessment Model (SAM) and its application on the Kopaonik-Jastrebac Spa Zone (Serbia). Tour. Manag. Perspect. 2020, 36, 100753. [CrossRef]

44. du Cros, H. A new model to assist in planning for sustainable cultural heritage tourism. Int. J. Tour. Res. 2001, 3, 165-170. [CrossRef]

45. Laing, J.; Wheeler, F; Reeves, K.; Frost, W. Assessing the experiential value of heritage assets: A case study of a Chinese heritage precinct, Bendigo, Australia. Tour. Manag. 2014, 40, 180-192. [CrossRef]

46. McKercher, R.; Ho, P. Assessing the tourism potential of smaller cultural and heritage attractions. J. Sustain. Tour. 2006, 14, 473-488. [CrossRef]

47. Božić, S.; Tomić, N. Developing the Cultural Route Evaluation Model (CREM) and its application on the Trail of Roman Emperors, Serbia. Tour. Manag. Perspect. 2016, 17, 26-35. [CrossRef]

48. Antić, A.; Tomić, N.; Đorđević, T.; Marković, S.B. Promoting Palaeontological Heritage of Mammoths in Serbia Through a Cross-Country Thematic Route. Geoheritage 2021, 13, 7. [CrossRef]

49. Antić, A.; Tomić, N. Assessing the speleotourism potential together with archaeological and palaeontological heritage in Risovača Cave (Central Serbia). Acta Geoturistica 2019, 10, 1-11.

50. Antić, A.; Tomić, N.; Marković, S.B. Karst geoheritage and geotourism potential in the Pek River lower basin (eastern Serbia). Geogr. Pannoni. 2019, 23, 32-46. [CrossRef]

51. Boškov, J.; Kotrla, S.; Jovanović, M.; Tomić, N.; Lukić, T.; Rvović, I. Application of the Preliminary Geosite Assessment Model (GAM): The case of the Bela Crkva Municipality (Vojvodina, North Serbia). Geogr. Panonica 2015, 19, 146-152. [CrossRef]

52. Božić, S.; Tomić, N. Canyons and gorges as potential geotourism destinations in Serbia: Comparative analysis from two perspectives-general geotourists' and pure geotourists'. Open Geosci. 2015, 7, 531-546. [CrossRef]

53. Božić, S.; Tomić, N.; Pavić, D. Canyons as potential geotourism attractions of Serbia-comparative analysis of Lazar and Uvac canyons by using M-GAM model. Acta Geoturistica 2014, 5, 18-30.

54. Gelvez-Chaparro, J.; Barajas-Rangel, D.; Herrera-Ruiz, J.; Rios-Reyes, C.A. Introducción al Geopatrimonio kárstico del municipio de El Peñón (Santander), Colombia. Boletín Geol. 2020, 42, 147-167. [CrossRef]

55. Jonić, V. Comparative analysis of Devil's town and Bryce canyon geosites by applying the modified geosite assessment model (M-GAM). Res. Rev. Dep. Geogr. Tour. Hotel Manag. 2018, 47, 113-125. [CrossRef]

56. Pál, M.; Albert, G. Comparison of geotourism assessment models: And experiment in Bakony-Balaton UNSECO Global Geopark, Hungary. Acta Geoturistica 2018, 9, 1-13. [CrossRef]

57. Tomić, N.; Marković, S.B.; Korać, M.; Mrđić, N.; Hose, T.A.; Vasiljević, D.J.A.; Jovičić, M.; Gavrilov, M.B. Exposing mammoths-from loess research discovery to public palaeontological park. Quat. Int. 2015, 372, 142-150. [CrossRef]

58. Tomić, N.; Antić, A.; Marković, S.B.; Đorđević, T.; Zorn, M.; Valjavec, M.B. Exploring the potential for speleotourism development in eastern Serbia. Geoheritage 2019, 11, 359-369. [CrossRef]

59. Tomić, N.; Marković, S.B.; Antić, A.; Tešić, D. Exploring the potential for geotourism development in the Danube region of Serbia. Int. J. Geoheritage Parks 2020, 8, 123-139. [CrossRef]

60. Tičar, J.; Tomić, N.; Valjavec, M.B.; Zorn, M.; Marković, S.B.; Gavrilov, M.B. Speleotourism in Slovenia: Balancing between mass tourism and geoheritage protection. Open Geosci. 2018, 10, 344-357. [CrossRef]

61. Vukoičić, D.; Milosavljević, S.; Valjarević, A.; Nikolić, M.; Srećković-Batoćanin, D. The evaluation of geosites in the territory of National park Kopaonik“ (Serbia). Open Geosci. 2018, 10, 618-633. [CrossRef] 
62. Vuković, S.; Antić, A. Speleological approach for geotourism development in Zlatibor county (west Serbia). Turizam 2019, 23, 53-68. [CrossRef]

63. Antić, A.; Tomić, N.; Đorđević, T.; Radulović, M.; Đević, I. Speleological objects becoming show caves: Evidence from the Valjevo karst area in Western Serbia. Geoheritage 2020, 12, 1-12. [CrossRef]

64. Antić, A.; Tomić, N.; Marković, S.B. Karst-based geotourism in Eastern Carpathian Serbia: Exploration and evaluation of natural stone bridges. Geoconservation Res. 2020, 3, 62-80.

65. Bratić, M.; Marjanović, M.; Radivojević, A.R.; Pavlović, M. M-GAM method in function of tourism potential assessment: Case study of the Sokobanja basin in eastern Serbia. Open Geosci. 2020, 12, 1468-1485. [CrossRef]

66. Tomić, N.; Sepehriannasab, B.; Marković, S.B.; Hao, Q.; Lobo, H.A.S. Exploring the Preferences of Iranian Geotourists: Case Study of Shadows Canyon and Canyon of Jinns. Sustainability 2021, 13, 798. [CrossRef]

67. Pál, M.; Albert, G. Examining the Spatial Variability of Geosite Assessment and Its Relevance in Geosite Management. Geoheritage 2021, 13. [CrossRef]

68. Milenković, J. Evaluation of Geo-sites in the Podrinje-Valjevo Mountains with Respect to Geo-tourism Development. Geoheritage 2021, 13, 44. [CrossRef]

69. Lee, C.-F.; King, B.E. Using the Delphi method to assess the potential of Taiwan's hot springs tourism sector. Int. J. Tour. Res. 2008, 10, 341-352. [CrossRef]

70. Yu-Qi, L.; De-You, M.; Jing-Hong, S. Assessing development potential of hot spring tourism resources in Hunan province. Resour. Environ. Yangtze Basin 2012, 6, 692-699.

71. Xian, W.; Zha, L. Quantitative assessment and development strategy for hot springs tourism destination in Wan-Jiang urban belt. Resour. Environ. Yangtze Basin 2012, 11, 1323-1329.

72. Lazić, L.; Pavić, D.; Stojanović, V.; Tomić, P.; Romelić, J.; Pivac, T.; Košić (Pavlica), K.; Besermenji, S.; Kicošev, S.; Đermati, Z.; et al. Protected Natural Assets and Ecotourism in Vojvodina; Faculty of Sciences, Department of Geography, Tourism and Hotel Management: Novi Sad, Serbia; University of Novi Sad: Novi Sad, Serbia, 2008.

73. Puzović, S.; Panjković, B.; Tucakov, M.; Stojnić, N.; Sabadoš, K.; Stojanović, T.; Vig, L.; Marić, B.; Tešić, O.; Kiš, A.; et al. Upravljanje Prirodnom Baštinom u Vojvodini (Natural Heritage Management in Vojvodina); Pokrajinski Sekretarijat za Urbanizam: Novi Sad, Serbia, 2015. 